\title{
Complete Nucleotide Sequence and Genome Organization of Broad Bean Wilt Virus 2*
}

\author{
Shigeo NAKAMURA**, Takayoshi IWAI***** and Ryoso HonKURA**,†
}

Key words : fabavirus, nucleotide sequence, genome organization.

Broad bean wilt virus (BBWV) is a member of the fabavirus group, which has recently been classified into two species BBWV-1 and BBWV-2. The former is the type member of the Genus Fabavirus ${ }^{4}$. BBWV has a wide host range among dicotyledons and some families of monocotyledons and is widely distributed throughout the world ${ }^{13}$. BBWV has a bipartite genome, consisting of two positive-strand RNA molecules designated as RNA1 $\left(M_{\mathrm{r}} 2 \times 10^{6}\right)$ and RNA2 $\left(M_{\mathrm{r}} 1.5 \times 10^{6}\right)$. Both genomic RNAs are separately encapsidated into two species of icosahedral particles with different sedimenting properties, built up by $42 \mathrm{kDa}$ and $26 \mathrm{kDa}$ coat proteins ${ }^{3)}$. Fabaviruses have been included in the Family Comoviridae together with the comoviruses and the nepoviruses. Both the comoviruses and the nepoviruses have been well investigated, whereas the fabaviruses have not been characterized at the molecular level ${ }^{4)}$. We present the complete nucleotide sequences of both BBWV-2 RNA1 and RNA2, and compare the deduced translation products of BBWV-2 with those of related viruses.

The MB7 isolate of BBWV-2, originally isolated from broad bean (Vicia faba) leaves with showing mosaic symptoms, was propagated in broad bean ${ }^{9}$. Broad bean leaves infected with MB7 were homogenized in two volumes $(\mathrm{v} / \mathrm{w})$ of $0.1 \mathrm{M}$ phosphate buffer ( $\mathrm{pH} 7.0$ ) containing $10 \mathrm{mM}$ EDTA and 0.5\% 2-mercaptoethanol and in one volume $(\mathrm{v} / \mathrm{w})$ of carbon tetrachloride. After centrifugation of the homogenate at $9000 \times g$ for $10 \mathrm{~min}$, $1 \%$ Triton $\mathrm{X}-100$ was added to the aqueous phase. The clarified solution was layered onto a $20 \%(\mathrm{w} / \mathrm{v})$ sucrose cushion, and centrifuged at $80,000 \times g$ for $2 \mathrm{hr}$. The pellet was dissolved in phosphate buffer and further purified by repeated differential centrifugation.

Virus preparation was treated with SDS and proteinase $\mathrm{K}$ followed by SDS-phenol to extract viral $\mathrm{RNA}^{8}$. Purified viral RNAs were reverse-transcribed by priming with oligo (dT) or random hexanucleotides using TimeSaver cDNA Synthesis Kit (Pharmacia). The
cDNAs were cloned into the Eco RI site of pBluescript $\mathrm{SK}+$ (Stratagene). Cloning of the $5^{\prime}$ ends was performed
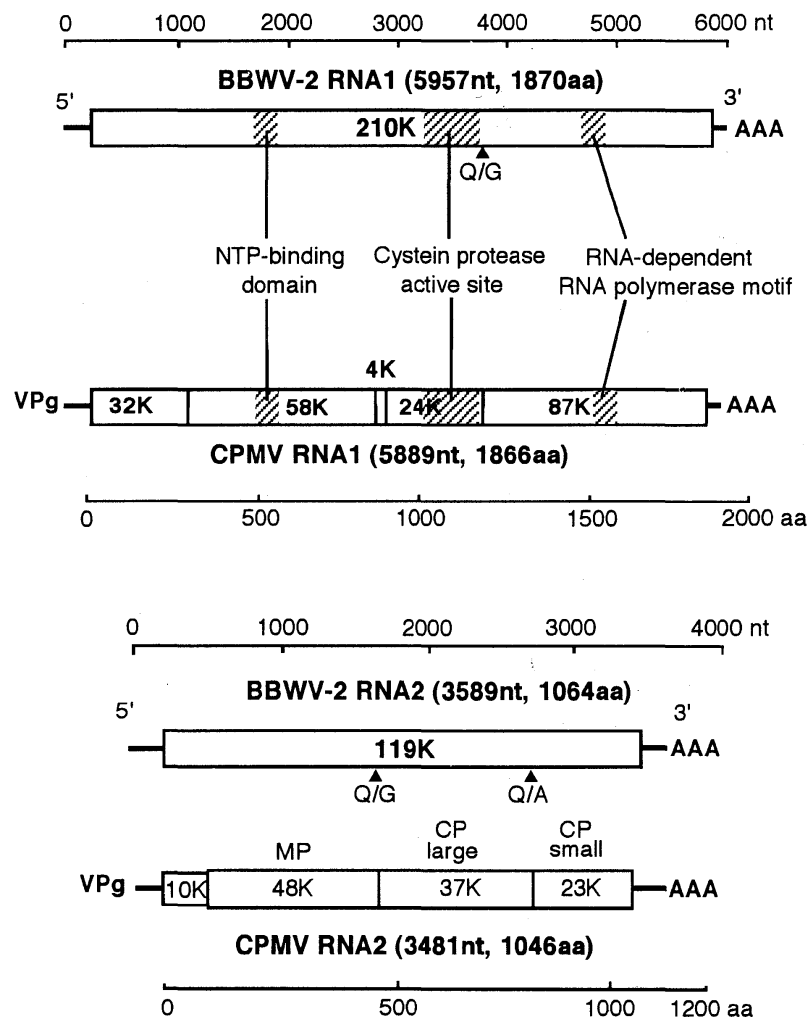

Fig. 1. Proposed genomic organizations of BBWV-2 RNA1 and RNA2 and comparisons with CPMV. Thick lines indicate non-coding sequences and large boxes represent the long ORFs. Shaded areas indicate the conserved amino acid sequences. Closed triangles are the predicted cleavage sites of BBWV-2 polyproteins. VPg, genome-linked viral protein; AAA, 3'poly(A) tail ; MP, movement protein ; $\mathrm{CP}$, coat protein.

* The nucleotide sequence data reported in this paper will be appear in the DDBJ/EMBL/GeneBank nucleotide sequence databases under the accession numbers AB013615 and AB013616.

** Miyagi Prefecture Agricultural Research Center, Takadate-Kawakami, Natori 981-1243, Japan＼cjkstart宮城県農業センター

*** Present address : National Institute of Agrobiological Resources, Kan-nondai, Tsukuba 305-8602, Japan 現在：農業 生物資源研究所

† Present address : Sendai Agricultural Extension Center of Miyagi Prefecture, Tsutsumidori-amamiyamachi, Aoba-ku, Sendai 981-0914, Japan 現在：仙台地域農業改良普及センター 
using the $5^{\prime}$ RACE System (GIBCO BRL). The cDNA clones covering the complete genome were sequenced and analysed as described previously ${ }^{8)}$.

RNA1 is 5957 nucleotides in length, excluding the $3^{\prime}$ poly(A) tail and contains a single long open reading frame (ORF) of 5613 nucleotides extending from nucleotide 235 to 5847 (Fig. 1). The protein encoded by the ORF, consisting of 1870 amino acids, has a predicted $M_{\mathrm{r}}$ of $210 \mathrm{kDa}$. The amino acid sequence of the RNA1coded $210 \mathrm{kDa}$ protein was compared with that of cowpea mosaic comovirus $(\mathrm{CPMV})^{6}$, cowpea severe mosaic comovirus (CPSMV) ${ }^{2}$ and red clover mottle comovirus $(\mathrm{RCMV})^{12}$, revealing that the size and genetic organization of BBWV-2 RNA1 is similar to that of the comovirus. As shown in Fig. 1, three conserved motifs, the NTP-binding, the protease and the RNA-dependent RNA polymerase, were identified at positions similar to those of comoviruses. The consensus sequences of the motifs were well conserved among BBWV-2 and three comoviruses (Fig. 2). In rabbit reticulocyte lysate, BBWV-2 RNAs directed the large polypeptide of approximately $200 \mathrm{kDa}$ (Fig. 3). These results suggest that the $210 \mathrm{kDa}$ protein encoded by BBWV-2 RNA1 is a polyprotein and is proteolytically cleaved by a virusencoded protease to yield the mature viral proteins as described for comoviruses ${ }^{2,6,12)}$. For comoviruses, four dipeptides, $\mathrm{Q} / \mathrm{S}, \mathrm{Q} / \mathrm{A}, \mathrm{Q} / \mathrm{M}$ and $\mathrm{Q} / \mathrm{G}$ are shown to be cleavage sites of polyproteins by virus-coded protein. In the $210 \mathrm{kDa}$ protein of $\mathrm{BBWV}-2$, a $\mathrm{Q} / \mathrm{G}$ at position $1171-1172$ is the most probable cleavage site of the protease/polymerase junction because of the resulting size of the mature polymerase. The predicted polymer- ase domain at position 1172-1870 of BBWV-2 shows $39.8 \%, 40.7 \%, 41.0 \%$ and $29.8 \%$ identities with the corresponding regions of $\mathrm{CPMV}^{6}$, $\mathrm{CPSMV}^{2)}, \mathrm{RCMV}^{12)}$ and grapevine fanleaf nepovirus $(\mathrm{GFLV})^{10)}$, respectively, whereas identities between the $\mathrm{N}$-terminal domain at position 1-1171 of BBWV-2 and the corresponding regions of other viruses are 28.6\% (CPMV), 28.5\% (CPSMV), 27.4\% (RCMV) and 21.5\% (GFLV). These results indicate that BBWV-2 is closely related to the comovirus rather than the nepovirus.

RNA2 is 3589 nucleotides in length excluding the $3^{\prime}$ poly(A) tail. A single long ORF of 3195 nucleotides extending from nucleotide 222 to 3416 is present (Fig. 1). The protein encoded by the ORF is 1064 amino acids in length with a predicted $M_{\mathrm{r}}$ of $119 \mathrm{kDa}$. All comovirus RNA2s sequenced to date have the second in-phase AUG codon producing smaller polyprotein ${ }^{1,7,1,14)}$. In the BBWV-2 RNA2, such a second in-phase AUG is also present at position 607-609. Whether the second AUG serves as the initiation of the smaller polyprotein is unknown. In rabbit reticulocyte lysate, however, the 105 $\mathrm{kDa}$ polypeptide, which agrees with the calculated $M_{\mathrm{r}}$ of the second AUG product, is favored over the $120 \mathrm{kDa}$ polypeptide, which is expected for the first AUG product (Fig. 3). Two proteolytic processing sites, a $Q / G$ at position $465-466$ and a Q/A at position $867-868$, within the $119 \mathrm{kDa}$ protein have been deduced by comparison with that of patchouli mild mosaic fabavirus ${ }^{5}$. These results suggest that the BBWV-2 RNA2 is translated into a polyprotein and is divided into three mature proteins. Of the resulting three proteins, central $(44 \mathrm{kDa})$ and $\mathrm{C}$-terminal $(22 \mathrm{kDa})$ proteins are predicted to be the

a) NTP-binding domain

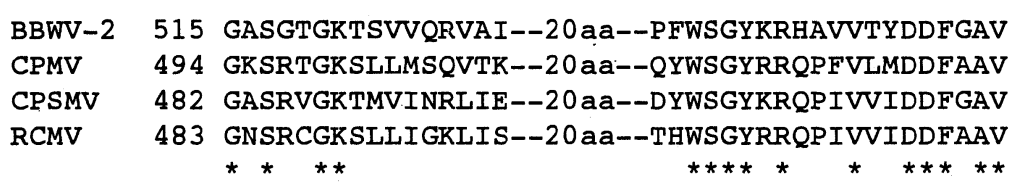

b) Cysteine protease domain

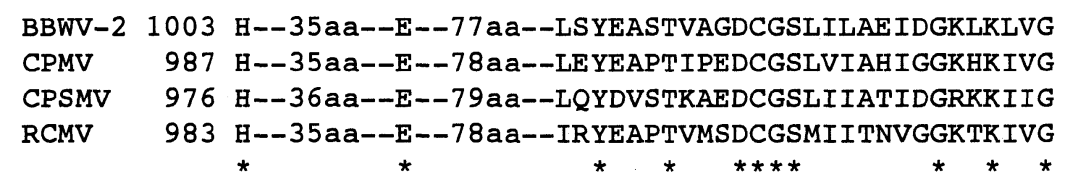

c) Polymerase domain

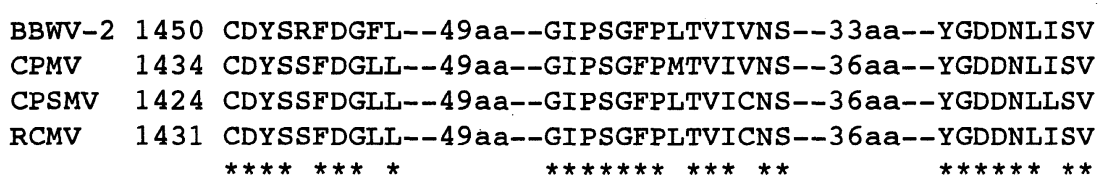

Fig. 2. Alignment of the four domains identifying the NTP-binding protein (a), the cysteine protease (b) and the RNA-dependent RNA polymerase (c) between BBWV-2, CPMV, CPSMV and RCMV. Asterisks indicate identical residues in all four sequences. Numbers to the left of the sequence refer to amino acid residue position in each viral polyprotein. 


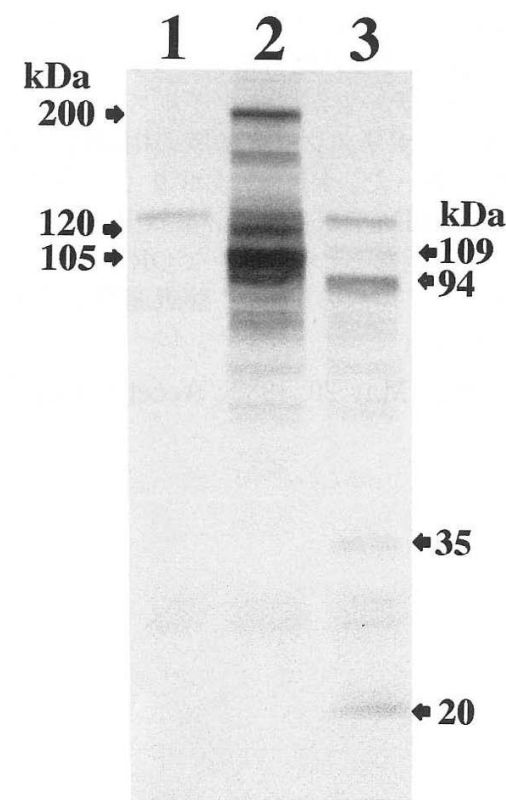

Fig. 3. Analysis of in vitro translation products encoded by BBWV-2 RNAs in rabbit reticulocyte lysate. Lane 1, no RNA; lane 2, translation products of BBWV-2 RNAs prepared from purified virions; lane 3 , translation products of brome mosaic virus RNAs. Translation reactions were performed by using ECL in vitro translation system (Amersham) combined with lysate from Promega. Reaction mixtures were separated on 5-20\% linear gradient SDS-polyacrylamide gel (ATTO Corp.). Translation products were then detected by an enhanced chemiluminescence system (Amersham).

coat proteins, because the molecular weights calculated from amino acid sequences well agree with the values estimated by SDS-PAGE of purified virion, $40 \mathrm{kDa}$ and $24 \mathrm{kDa}$, respectively. The overall amino acid identities of the BBWV-2 $119 \mathrm{kDa}$ protein compared with those of comoviruses are 21.1\% (CPMV $\left.{ }^{14)}\right), 21.7 \%\left(\mathrm{CPSMV}^{1)}\right)$, $20.0 \%\left(\mathrm{RCMV}^{11)}\right)$ and $21.9 \%$ (bean pod mottle comovirus, $\left.\mathrm{BPM} V^{7)}\right)$.

In this report, the $5^{\prime}$ ends of both BBWV-2 RNA1 and RNA2 were cloned by the RACE method, in which the 1st strand cDNAs were tailed with $\mathrm{dC}$ by terminal deoxynucleotidyl transferase. Therefore, the extreme $5^{\prime}$ $\mathrm{G}$ residue(s) may be missing, and in the case of $\mathrm{G}: \mathrm{C}$ rich cDNA, non-specific priming of second strand cDNA synthesis with the deoxyinosine-containing anchor primer may result in truncated products. To determine the sequences of the extreme $5^{\prime}$ ends of the RNAs, the dA-tailing RACE and/or the direct RNA sequencing should also be employed. The genome organization of BBWV-2 RNA1- and RNA2-encoded proteins shown in Fig. 1 is hypothetical. Because none of the potential cleavage sites have been confirmed experimentally, the exact sizes and proteolytic cleavage sites of viral gene products need to be confirmed both in vitro and in vivo.
We thank Drs. Y. Honda and Y. Mikoshiba of the National Agricultural Research Center for helpful advice in classifying the MB7 isolate. We are also grateful to Dr. T. Kuroda of Iwate Biotechnology Research Center for useful suggestions and discussion.

\section{Literature cited}

1. Chen, X. and Bruening, G. (1992). Nucleotide sequence and genetic map of cowpea severe mosaic virus RNA 2 and comparisons with the RNA 2 of other comoviruses. Virology $187:$ 682-692.

2. Chen, X. and Bruening, G. (1992). Cloned DNA copies of cowpea severe mosaic virus genomic RNAs: infectious transcripts and complete nucleotide sequence of RNA1. Virology 191 : 607-618.

3. Doel, T.R. (1975). Comparative properties of type, nasturtium ringspot and petunia ringspot strains of broad bean wilt virus. J. Gen. Virol. 26 : 95-108.

4. Goldbach, R., Martelli, G.P. and Milne, R.G. (1995). Family Comoviridae. In Virus Taxonomy, SpringerVerlag, New York, pp. 341-347.

5. Kawashima, H., Ikegami, M., Natsuaki, T., Okuda, S., Kageyama, Y. and Sugimura, N. (1996). The nucleotide sequence of the coat protein gene of patchouli mild mosaic virus. Ann. Phytopathol. Soc. Jpn. 62: 341-342 (Abstr. in Japanese).

6. Lomonossoff, G.P. and Shanks, M. (1983). The nucleotide sequence of cowpea mosaic virus B RNA. EMBO J. 2 : 2253-2258.

7. MacFarlane, S.A., Shanks, M., Davies, J.W., Zlotnick, A. and Lomonossoff, G.P. (1991). Analysis of the nucleotide sequence of bean pod mottle virus middle component RNA. Virology 183 : 405-409.

8. Nakamura, S., Honkura, R., Iwai, T., Ugaki, M. and Ohashi, Y. (1996). The complete nucleotide sequence of bean yellow mosaic virus genomic RNA. Ann. Phytopathol. Soc. Jpn. $62: 472-477$.

9. Nakamura, S. and Honkura, R. (1997). Characterization of some viruses isolated from broad bean in Miyagi Prefecture. Annu. Rep. Soc. Plant Prot. North Japan 48 : 80-84 (in Japanese).

10. Ritzenthaler, C., Viry, M., Pinck, M., Fuchs, M. and Pinck, L. (1991). Complete nucleotide sequence and genetic organization of grapevine fanleaf nepovirus RNA1. J. Gen. Virol. 72 : 2357-2365.

11. Shanks, M., Stanley, J. and Lomonossoff, G.P. (1986). The primary structure of red clover mottle virus middle component RNA. Virology 155: 697-706.

12. Shanks, M. and Lomonossoff, G.P. (1992). The nucleotide sequence of red clover mottle virus bottom component RNA. J. Gen. Virol. 73 : 2473-2477.

13. Taylor, R.H. and Stubbs, L.L. (1972). Broad bean wilt virus. CMI/AAB Descriptions of Plant Viruses No. 81.

14. van Wezenbeek, P., Verver, J., Harmsen, J., Vos, P. and van Kammen, A. (1983). Primary structure and gene organization of the middle-component RNA of cowpea mosaic virus. EMBO J. 2 : 941-946. 


\section{和 文 摘 要}

中村茂雄・岩井孝尚・本藏良三 : ソラマメウイルトウイルス 2 RNA の全塩基配列

宮城県内のモザイク症状ソラマメから分離したソラマメウイ ルトウイルス2（BBWV-2）MB7 株のゲノム RNA をクローニ ングし，その全塩基配列を決定した。RNA1 はポリ（A）鎖を除 いて 5847 塩基から成り， $210 \mathrm{kDa}$ (1870アミノ酸残基) のタン パク質をコード可能な一つの大きな ORF が存在した。この
ORF 産物はコモウイルス, 次いでネポウイルスの RNA1 翻訳 産物と相同性が高く, NTP 結合モチーフ, プロテアーゼモチー フ,ポリメラーゼモチーフがコモウイルスのそれとほほ同じ位 置に見いだされた。ポリメラーゼ領域の相同性はコモウイルス と 39.8〜 41.0\%であった。RNA2 はポリ（A）鎖を除いて 3589 塩基から成り, $119 \mathrm{kDa}$ (1064アミノ酸残基) のタンパク質をコ 一ドすることが可能な一つの大きな ORF が存在した。この $\mathrm{ORF}$ 産物とコモウイルスの RNA2 翻訳産物との相同性は 20.0 〜21.9\% と低かった。

(Received May 20, 1988 ; Accepted July 23, 1998) 